\title{
Opinions of the Sixth Year Students Who Participated in Outdoor Learning Activity Practices for Science
}

\author{
Gulbin Ozkan ${ }^{1, *}$, Hatice Turan ${ }^{1} \&$ Unsal Umdu Topsakal ${ }^{1}$ \\ ${ }^{1}$ Faculty of Education, Yildiz Technical University, Istanbul, Turkey \\ *Correspondence: Faculty of Education, Yildiz Technical University, Istanbul, Turkey. Tel: 90-212-383-5570. E-mail: \\ gozkan@yildiz.edu.tr
}

Received: March 22, 2020

Accepted: March 27, 2020 Online Published: April 20, 2020

doi:10.5430/wje.v10n2p150

URL: https://doi.org/10.5430/wje.v10n2p150

\begin{abstract}
In this study, it is aimed to investigate the effects of learning 6th-grade students on the resultant force with active participation, using physical activity and applying four outdoor learning activities to their views on science. In this study, a case study, which is one of the qualitative research methods, was used to examine the students' views in depth. Data were collected open-ended questionnaire. The implementation was carried out in the fall semester of the 2018-2019 academic year. The sample of the study consisted of 25 sixth grade middle school students. The data were analyzed using content analysis. According to the findings obtained from the data analysis, it was determined that the students had positive opinions about science teaching with out-of-class activities. Also, out-of-class activities have changed the way students think about science.
\end{abstract}

Keywords: outdoor learning, activity, science education, middle school students

\section{Introduction}

Science is an attempt to systematically examine the observed natural phenomena and to reveal the events that have not yet been observed. Science is an important part of our life as every event in nature is a subject of science. Science consists of concepts, generalizations, principles, theories, and laws of nature, as well as studying living and inanimate beings that makeup nature. With the development of technology and education also show development and change. In line with these developments and changes, the direct transfer of information to students in science education has lost its validity (Kulakligil, 2016). In the Science Curriculum, it is envisaged to conduct courses in learning environments (problem, argumentation, collaborative learning, etc.) based on the student. In the learning-teaching process, the student is an individual who actively participates in learning, conducts research, asks and lives (MEB, 2018).

Physical activity is an international term used to describe body movements using energy. The simplest definition is to move the body to spend energy. It needs action to sustain human life in a healthier and more qualified manner (Koç, 2011). Education that supports the physical activities of students in schools is usually only physical education. Physical education contributes greatly to the child's physical fitness, perceptual-motor development, social-emotional development, development of learning capacity, and the habits of using free time in a positive and good way (Yenal, Çamlıyer, \& Saracaloğlu, 1999). Students often perform their physical activities at school during breaks and physical education classes. In science lessons, instead of learning by practicing activities that will enable them to act, they can also learn the subjects they can learn by performing physical activity, but they try to learn by sitting on their desk during the class hours.

Effective science education is possible by learning knowledge meaningfully at the level of concepts instead of memorization (Hançer, 2007). If students are actively involved in the subject, students can learn by living, observing and practicing (Kulakligil, 2016). When the students learn by doing, they build the concepts about the subject faster and more accurately in their mind. Thus, learning becomes more permanent. Some information in the field of science education should be supported by an out-of-class learning environment to make learning meaningful and permanent. If out-of-class activities are prepared based on situations that students may encounter in daily life, they contribute significantly to the development of problem-solving and critical thinking skills of students. Out-of-class activities are 
important in raising awareness in science education, enriching and diversifying students' learning experiences, socializing students, and increasing their interest and attitude towards the lesson (Karademir, 2013).

Attitude is a tendency that regulates individuals' thoughts, feelings and behaviours about objects, events or other people. Attitudes can change through learning because there are trends gained later (Demir \& Çetin, 2012). The source of information, belief, and reliability are effective in changing attitudes. For example, the individual and the teacher are very effective in increasing or changing students' attitudes towards science lessons.

There are many studies in the literature about the classroom learning environment and physical activity. These studies are; the effects of out-of-class learning environments on academic achievement, creativity and motivation of students in a 5th-grade science course (Kulakligil, 2016), research of physical activity levels of 10-12 age group children (Urlu, 2014), within the scope of science and technology lesson, determining the aims of realizing "out-of-school learning activities" through planned behavioural theory (Karademir, 2013) In the literature, many studies have been carried out on my teaching of the subject of Force and Energy. The effects of writing activities for learning force subject to these studies (Günel, Uzoğlu, \& Büyükkasap, 2009), 6th-grade students' determination of alternative concepts about force and motion and examination of conceptual development (Seçer, 2008), 6th class force and movement unit's social teaching with a constructivist learning approach (Aydin, 2008) can be given as an example. However, there is no study in the literature about the effect of out-of-class learning activities on students' views.

In this study, it is aimed to investigate the effects of learning 6th-grade students on the Resultant Force with active participation, using physical activity and applying four out-of-class activities to their views on science.

\section{Method}

\subsection{Design of the Research}

In this study, a case study, which is one of the qualitative research methods, was used to examine the students' views in depth. Data were collected before and after implementation with qualitative data collection tools. The implementation was carried out in the fall semester of the 2018-2019 academic year.

\subsection{Participants}

The sample of the study consisted of 25 sixth grade middle school students. A purposeful sampling method was used in the research. The research group was formed from students who had not participated in outdoor activities before, taking the opinion of the science teacher.

\subsection{Data Collection}

The data were collected qualitatively. The questions included in the pre-test and post-test of the open-ended questionnaire are presented below. After the questions were written, they were checked by a science teacher who had 12 years of experience in the field and by a faculty member with a specialization in science education. The question form was given its final form in line with the opinions of the experts. An open-ended questionnaire was created by researchers as a data collection tool.

Pre-test Questions;

1. What do you think about the importance of the Science course?

2. What are your favorite aspects of the Science course?

3. What aspect do you dislike most about the Science course?

4. How would you like to teach the Science course? Why?

Post-Test Questions;

1. What do you think about the importance of the Science course?

2. What are your favorite aspects of the Science course?

3. What aspect do you dislike most about the Science course?

4. How would you like to teach the Science course? Why?

5. What do you think about the activities covered in the lesson?

6 . What is your favourite activity? Why? 
7. What is your most challenging activity? Why?

\subsection{Data Analysis}

In this study, the data were analyzed using content analysis. Qualitative analyzes are techniques that help us understand how social situations, events, and phenomena occur. Qualitative research involves in-depth study and study of variables rather than measurement such as quantitative research. However, qualitative methods have the opportunity and advantage to be converted into quantitative data at any time (Büyüköztürk, 2004).

In the content analysis method, which is also called as a method of analysis, the main purpose is from open-ended questions, interviews, etc. prepared and applied by the researcher. The qualitative data obtained is converted into quantitative terms. In studies conducted using the content analysis method, qualitative data obtained from written, verbal or other materials are converted into numerical data as a result of systematic, objectively classification according to their meanings and some inferences are made (Büyüköztürk, 2004).

Content analysis stages begin with the coding of qualitative data first. The coding of the data is done according to the concepts obtained from the data. The researcher divides the data into meaningful sections as a result of his examination of the data he obtained. He tries to find out what each episode expresses conceptually. After the coding of the data, it is passed to find the categories that appear. At this stage, the researcher categorizes the codes using the induction method (Seçer, 2008). After this stage, the codes are explained in a language that the reader will understand.

In this study, the information obtained from the pre-test and post-test questions applied to the study group were categorized by coding according to their similarities. The coded qualitative data were numbered according to the number of respondents and were tabulated as frequency numbers and percentages. Thus, qualitative data are also shown as quantitative data. The research data was then coded by another researcher and the agreement between the two raters was determined as $92 \%$.

\subsection{Procedure}

In this study, the subject of resultant force was explained in two lesson hours by applying four out-of-class activities to a group of 25 people. Out-of-class activities were developed by researchers. While developing the activities, attention was paid to be suitable for the gains. Expert opinion was consulted before the activities were implemented. Two of the experts are faculty members who are experienced in the field of science and the other is 8 years of an experienced science teacher. The activities were finalized in line with the opinions of the experts. Out-of-class activities are presented below.

\subsubsection{Activity 1: Pulling Rope}

Acquisition: Students compare the balanced and unbalanced forces by observing the state of motion of objects.

Application: An equal number of students are lined up on both ends of the rope. Students start pulling the rope at the same time. Whether the rope is moving or which direction it is moving is determined and the reason is discussed.

\subsubsection{Activity 2: To Whom?}

Acquisition: Students compare the balanced and unbalanced forces by observing the state of motion of objects.

Application: It can be applied individually or in groups. In individual practice, two students standing at the same level as their hands towards each other in the same position mutually push their hands towards each other and apply force. Group is applied in groups of two. Each group is lined up to stand close to each other and hold each other and everyone can use one hand. Both groups push their hands towards each other and apply force. It is observed who is moving towards the side and the reason is discussed.

\subsubsection{Activity 3: Moving Ping-Pong}

Acquisition: Students compare the balanced and unbalanced forces by observing the state of motion of objects.

Application: A ping-pong ball is placed inside a pipe with two ends open and in the middle of it. Two people begin to blow into the ping-pong ball from each end. The side of the ping-pong ball moving is observed and its cause is discussed.

\subsubsection{Activity 4: Outgoing!}

Acquisition: Students show the direction and magnitude of the force acting on an object (It is not entered in the size of the force.)

Application: Five students are lined up with their shoulders touching each other. Any primary student pushes the four 
students next to him with one hand, then the second student - the first-pushed student - pushes the next three students with one hand, then the third student pushes the two students next to him, the fourth student pushes a student next to him, and finally, the fifth student pushes his hand towards the void. Afterward, the students who observed the activity were asked by which of the five students applied the most and least force, and the activity was repeated by changing the locations of the five students.

\section{Findings}

The findings obtained from the content analysis made on the data obtained from the questionnaires applied before and after the out-of-class activity application are included in this section.

"What do you think about the importance of the Science course?" was asked to the students. The frequency of the opinions obtained as a result of the content analysis of the answers they gave to the question before and after the application of out-of-class activities are given in Table 1.

Table 1. The Importance of Science

\begin{tabular}{|c|c|c|c|c|}
\hline \multirow{2}{*}{ The Importance of Science } & \multicolumn{2}{|l|}{ Pre-test } & \multicolumn{2}{|l|}{ Post-test } \\
\hline & Frequency & Percentage & Frequency & Percentage \\
\hline $\begin{array}{l}\text { It allows us to explain the events we } \\
\text { experience in daily life. }\end{array}$ & 1 & $4 \%$ & 9 & $36 \%$ \\
\hline It allows us to learn the planets. & 2 & $8 \%$ & 6 & $24 \%$ \\
\hline It is associated with other courses. & 2 & $8 \%$ & 4 & $16 \%$ \\
\hline It allows us to learn topics. & 9 & $36 \%$ & 10 & $40 \%$ \\
\hline It is helpful in the future. & 7 & $28 \%$ & 9 & $36 \%$ \\
\hline It is important for our careers. & 6 & $24 \%$ & 6 & $24 \%$ \\
\hline
\end{tabular}

Many of the students think that before applying out-of-class activities, the science class is mostly taught solely for teaching subjects. After the application, they started to realize that we learned in the science course of many situations that we practiced unconsciously in daily life.

"What are your favorite aspects of the science class?" was asked to the students. The frequency of the opinions obtained as a result of the content analysis of the responses they gave before and after the application of out-of-class activities to the question is given in Table 2 .

Table 2. Popular Aspects of the Science Course

\begin{tabular}{lllll}
\hline \multirow{2}{*}{ Popular aspects of the Science course } & Pre-test & \multicolumn{3}{l}{ Post-test } \\
\cline { 2 - 5 } & Frequency & Percentage & Frequency & Percentage \\
\hline Being fun & 5 & $20 \%$ & 8 & $32 \%$ \\
Containing an activity & 1 & $4 \%$ & 4 & $16 \%$ \\
Learning something new & 2 & $8 \%$ & 3 & $12 \%$ \\
Doing homework & 2 & $8 \%$ & 2 & $8 \%$ \\
Developing project & 3 & $12 \%$ & 3 & $12 \%$ \\
Being interesting & 2 & $8 \%$ & 2 & $8 \%$ \\
Solving tests & 3 & $12 \%$ & 3 & $12 \%$ \\
Learning lessons from the smartboard & 8 & $32 \%$ & 4 & $16 \%$ \\
Doing experiments & 7 & $28 \%$ & 6 & $24 \%$ \\
Learning science topics & 9 & $36 \%$ & 5 & $20 \%$ \\
\hline
\end{tabular}

Since the students are project class, they make projects with their teachers in the lessons. They also handle most of the lessons by solving tests on the smartboard and the smartboard. The students stated that processing the lesson from the smart board is their favorite part of the lesson before practicing out of class activities. After the implementation, they stated that they liked to do activities in the lesson more than working on the smartboard and 
found it fun.

"What are the most disliked aspects of the science course of the students?" was asked to the students. The frequency of the opinions obtained as a result of the content analysis of the answers they gave to the question before and after the application of out-of-class activities are given in Table 3.

Table 3. Dislikes of the Science Course

\begin{tabular}{lllll}
\hline \multirow{2}{*}{ Dislikes of the Science course } & Pre-test & \multicolumn{3}{l}{ Post-test } \\
\cline { 2 - 5 } & Frequency & Percentage & Frequency & Percentage \\
\hline Not doing activity & 0 & $0 \%$ & 3 & $12 \%$ \\
Not doing experiment & 1 & $4 \%$ & 3 & $12 \%$ \\
Writing a lot & 12 & $48 \%$ & 12 & $48 \%$ \\
Difficult to understand terms & 3 & $12 \%$ & 3 & $12 \%$ \\
Science course is related to numbers & 2 & $8 \%$ & 2 & $8 \%$ \\
Not teaching the lesson from the book & 3 & $12 \%$ & 2 & $8 \%$ \\
Not having a laboratory in the school & 7 & $28 \%$ & 5 & $20 \%$ \\
Difficult to understand science topics & 3 & $12 \%$ & 2 & $8 \%$ \\
Teacher factor & 2 & $8 \%$ & 0 & $0 \%$ \\
Not being able to examine with a & 3 & $12 \%$ & 0 & $0 \%$ \\
microscope & 2 & $8 \%$ & 3 & $12 \%$ \\
There is no aspect I do not like & & & \\
\hline
\end{tabular}

The students stated that they did not like to write most in a science lesson. None of the students had the idea of "not doing activity" before implementation. However, some students stated that they wanted the lesson to be passed through the activity continuously during and after the implementation. They complain about not being able to examine with a microscope because there is no laboratory in the students' school. However, after the implementation of out-of-class activities, the students realized that besides writing and teaching lessons from the smartboard, they could do different activities outside the laboratory. For this reason, fewer people in the post-test compared to the pre-test stated that they did not like not having a laboratory and not being able to make examinations with a microscope.

"How would you like the course of science to be taught? Why?" was asked to the students. The frequency of the opinions obtained as a result of the content analysis of the answers they gave to the question before and after the implementation of out-of-class activities are given in Table 4.

Table 4. Views on the Teaching of Science

\begin{tabular}{lllll}
\hline & Pre-test & & Post-test \\
\cline { 2 - 5 } Views on the teaching of Science & Frequency & Percentage & Frequency & Percentage \\
\hline $\begin{array}{l}\text { I would like to learn lessons by doing activities. } \\
\text { I would like the lesson to be taught by making it }\end{array}$ & 3 & $12 \%$ & 12 & $48 \%$ \\
more fun. & & $12 \%$ & 7 & $28 \%$ \\
I would like the lesson to be taught in a laboratory. & 5 & $20 \%$ & 1 & $12 \%$ \\
$\begin{array}{l}\text { I would like the lesson to be taught by experience } \\
\text { by doing it ourselves. }\end{array}$ & 3 & $12 \%$ & 3 & $12 \%$ \\
$\begin{array}{l}\text { I would like the lesson to be taught by } \\
\text { experimenting. }\end{array}$ & 4 & $12 \%$ & 1 & $4 \%$ \\
I would like the lesson to be taught by solving \\
problems.
\end{tabular}


The students stated that they found the activities enjoyable and instructive after the out-of-class activities. Also, students who love test solving, stated that learning about the resultant force after the activities is more fun and permanent than learning by solving the test and working from the smartboard.

"What do you think about the activities covered in the course?" was asked to the students. The frequency of the opinions obtained as a result of the content analysis of the answers given to the question after the implementation of out-of-class activities is given in Table 5 .

Table 5. Opinions about Activities

\begin{tabular}{lll}
\hline \multirow{2}{*}{ Opinions about activities } & Post-test \\
\cline { 2 - 3 } & Frequency & Percentage \\
\hline Enjoyable & 16 & $64 \%$ \\
Increasing interest in the science lesson & 6 & $24 \%$ \\
Helpful in understanding science topics & 5 & $20 \%$ \\
Directly related to science topics & 4 & $16 \%$ \\
Instructive & 4 & $16 \%$ \\
Permanent & 3 & $12 \%$ \\
\hline
\end{tabular}

Looking at Table 5, it was seen that the highest frequency is in the "fun" code. In other words, students find activities educational. Students were given the concepts of resultant force before applying 4 out-of-class activities in the lesson and their estimations about these concepts were taken. Then, the definition of the concept of force was made by applying force to each other physically. For example; to activate a standing object, a student actuated his classmate by applying force, stopping his friend with a certain speed towards him and changing his direction. Then, students defined the concepts of "balanced force", "unbalanced force", "net force", "opposite direction force", "same direction force", "resultant force" through activities. Meanwhile, many of the students stated that the activities were very entertaining, they would normally handle this subject by writing on the smartboard and in the notebook, but in this way, it was more instructive and memorable.

"What is your favorite activity? Why?" was asked to the students. The frequency of the opinions obtained as a result of the content analysis of the responses given after the application of out-of-class activities to the question is given in Table 6.

Table 6. Students' Favorite Activities

\begin{tabular}{lll}
\hline & \multicolumn{2}{l}{ Post-test } \\
\cline { 2 - 3 } Favorite activities & Frequency & Percentage \\
\hline To Whom? & 12 & $48 \%$ \\
Pulling Rope & 10 & $40 \%$ \\
Outgoing & 6 & $24 \%$ \\
Moving Ping Pong & 5 & $20 \%$ \\
None & 1 & $4 \%$ \\
\hline
\end{tabular}

The reason why students love activities is "testing power", "teaching opposite forces", "having fun in class", "teaching to control power", "teaching to balance", "helping to understand the subject", "having fun", "in daily life They helped us learn what we practiced all the time ", creating competition ".

"What is the most challenging activity? Why?" was asked to the students. The frequency of the opinions obtained as a result of the content analysis of the responses given after the application of out-of-class activities to the question is given in Table 7. 
Table 7. The Most Challenging Activity

\begin{tabular}{lll}
\hline & \multicolumn{2}{l}{ Post-test } \\
\cline { 2 - 3 } The most challenging activity & Frequency & Percentage \\
\hline Pulling Rope & 20 & $80 \%$ \\
Moving Ping Pong & 3 & $12 \%$ \\
To Whom? & 3 & $12 \%$ \\
Outgoing & 1 & $4 \%$ \\
None & 2 & $8 \%$ \\
\hline
\end{tabular}

The students stated that they had difficulties more than the activities outside the classroom in the "Rope Pulling" activity. During the implementation of the out-of-class activity, there was competition among students who were groups at both ends of the rope. So they held the rope too tight when pulling the rope and most students' hands hurt. While answering this question, most of the reasons they stated for the activity of "rope pulling" commented as "our hands hurt", "required excessive force", "it was difficult to do teamwork", "there was a power difference", "it was a stressful activity". On the other hand, the students who find it difficult to be active in the "moving ping-pong" activity have commented as "because I am sick at this time" and "because I cannot use my breath in the right place and time". In "To Whom?" activity, the students commented that "I had difficulty in keeping balance while applying force to each other".

\section{Conclusion, Discussion and Suggestions}

In this study, it was aimed to investigate the effect of learning 6th-grade students on the Resultant Force with active participation, using physical activity and applying four out-of-class activities to their views on science. In this study, the data obtained qualitatively with open-ended questions were encoded and analyzed by the content analysis method. As a result of the data analysis, the findings obtained from the pre-test and post-test were compared in tables. According to the findings obtained from the data analysis, it was determined that the students had positive opinions about science teaching with outdoor activities. Also, outdoor activities have changed the positive way students think about science.

Students 'active participation in the course and their learning by doing-living can be increased, their interest in the course can be increased, a different perspective can be gained to science lesson and subjects by applying outdoor activities and the grounds for developing students' attitudes towards science lesson can be prepared.

In the study of the effects of out-of-class learning environments on academic achievement, creativity and motivation of students in a 5th-grade science course (Kulaklıgil, 2016), it was revealed that the academic achievements, creativity, and motivation of students in the experimental group, where teaching practices applied in out-of-class learning environments, were carried out. The reason for this was stated that out of class learning environments attracted the attention of students, aroused curiosity, increased their willingness to lessons and reduced their anxiety.

In parallel with the findings of this study, Yavuz and Balkan Kiyıc1 (2012) stated that out-of-school learning environments were made meaningful by interacting with abstract concepts through one-on-one interaction. Randler, Baumgartner, Eisele and Kienzle (2007) stated that by supporting education and training activities in formal education with out-of-school learning environments, existing learning will be reinforced and students' various affective characteristics will improve positively.

Outdoor activities can be used to develop positive thoughts for students' science class. Thus, the permanence of information in students can be supported, as it can be ensured that students connect with daily life.

In future researches, implementations can be made not only in science classes but also in other fields and their results can be examined.

The limitations of this study can be listed as follows: This study was carried out with sixth-grade students of a public school. Later studies can be carried out with other grade-level students. Also, the study was conducted only as a single group. Lack of control group constitutes the limitation of the study. For future studies, the same variables can be looked at comparatively between experimental and control groups. 


\section{References}

Aydın, S. (2008). İlköğretim 6. sınıffen ve teknoloji dersi kuvvet ve hareket ünitesinin sosyal yapılandırmacı öğrenme yaklaşımı çerçevesinde öğretimi. Yüksek Lisans Tezi. Balıkesir Üniversitesi, Fen Bilimleri Enstitüsü.

Büyüköztürk, Ş. (2004). Veri analizi el kitabı. Ankara.

Demir, C. G., \& Çetin, Ş. (2012). Matematik öğretimi tutum ölçeğinin geliştirilmesi. Gazi Üniversitesi Endüstriyel Sanatlar Ĕ̈itim Fakültesi Dergisi, 29, 59-65.

Günel, M., Uzoğlu, M., \& Büyükkasap, E. (2009). Öğrenme amaçlı yazma aktivitelerinin kullanımının ilköğretim seviyesinde kuvvet konusunu öğrenmeye etkisi. Gய̈, Gazi Eğitim Fakültesi Dergisi, 29(1), 379-399.

Hançer, A. H. (2007). Fen eğitiminde yapılandırmacı yaklaşıma dayalı bilgisayar destekli öğrenmenin kavram yanılgıları üzerine etkisi. Cumhuriyet Üniversitesi Sosyal Bilimler Dergisi, 31(1), 69-81.

Karademir, E., (2013). Öğretmen ve ögretmen adaylarının fen ve teknoloji dersi kapsamında "okul dişı ögrenme etkinliklerini” gerçekleştirme amaçlarının planlanmış davranış teorisi yoluyla belirlenmesi. Hacettepe Üniversitesi, Sosyal Bilimler Enstitüsü.

Koç, İ. (2011). 15-19 yaş bayan voleybol oyuncularında 8 haftalık antrenman programı boyunca uygulanan Kinesio ${ }^{\circledR}$ tape bantlamanın kuvvet ve esneklik performansına etkileri. Gazi Üniversitesi, Sağlık Bilimleri Enstitüsü.

Kulaklıgil, A. (2016). Sınıf Dışı Öğrenme Ortamlarında Gerçekleşen Öğretim Uygulamalarının 5. Sınıf Fen Bilimleri Dersinde Öğrencilerinin Akademik Başarı, Yaratıcılık Ve Motivasyonlarına Etkisi. Yüksek Lisans Tezi. Pamukkale Üniversitesi, Eğitim Bilimleri Enstitüsü.

MEB. (2018). Fen Bilimleri Dersi Öğretim Programı. Ankara: Talim ve Terbiye Kurulu Başkanlığı.

Randler, C., Baumgartner, S., Eisele, H., \& Kienzle, W. (2007). Learning at workstations in the zoo: A controlled evaluation of cognitive and affective outcomes. Visitor Studies, 10(2), 205-216. https://doi.org/10.1080/10645570701585343

Seçer, S., (2008). 6. Sınıf ögrrencilerinin kuvvet ve hareket konusundaki alternatif kavramlarının belirlenmesi ve kavramsal gelişimin incelenmesi. Yüksek Lisans Tezi. Balıkesir Üniversitesi / Fen Bilimleri Enstitüsü.

Urlu, Y. (2014). 10-12 Yaş Grubu Çocukların Fiziksel Aktivite Düzeylerinin Araştırılması (Antalya İli Örneği) Balıkesir Üniversitesi, Sağlık Bilimleri Enstitüsü.

Yavuz, M., \& Balkan Kıyıcı, F. (2012). Informal öğrenme ortamlarının ilköğretim öğrencilerinin fene karşı kaygı düzeylerinin değişmesine ve akademik başarılarına etkisi: Hayvanat bahçesi örneği. X. Ulusal Fen Bilimleri ve Matematik Eğitimi Kongresi Özet Kitabı. Niğde Üniversitesi Eğitim Fakültesi, Niğde.

Yenal, T. H., Çamlıyer, H., \& Saracaloğlu, A. S. (1999). İlköğretim ikinci devre çocuklarında beden eğitimi ve spor etkinliklerinin motor beceri ve yetenekler üzerine etkisi. Gazi Beden Eğitimi ve Spor Bilimleri Dergisi, 4(3), 15-24. https://doi.org/10.1501/sporm_0000000160 